Boiarchuk S. I., Bubin A. O. Pedagogical practice as an important component forming the professional competence of future preschool education

In the article the problem of forming the professional competence of the future preschool teachers during the pedagogical practice is actualized. The academic foundations of the competence approach to the modern teacher preparation are analyzed, the essence of the "professional competence» concept is revealed. Students pedagogical practice is determined as an integral part of pedagogical education, an essential factor in shaping the professional competence of the future specialists in the preschool education field.

The types of practice are characterized (pedagogical practice in the groups of very young children; educational practice of the fundamentals of natural science and local lore study; pedagogical practice in preschool children groups; educational practice (preparation to work in the summer period); summer pedagogical practice; pre-diploma pedagogical practice, after which students possess professional knowledge, skills, abilities necessary for fulfilling the duties of early and preschool children's teacher.

It is defined that during the pedagogical practice students develop their professional competencies such as the ability to solve complex problems and practical problems independently and comprehensively in the field of the development, education and upbringing of preschool children implementing the theory and methodology of preschool education; the ability to develop basic personality traits of the early and pre-school children; the ability to organize and guide the play (leading), artistic-speaking and artistic-productive activities of early and preschool children; the ability to develop healthy lifestyle habits of early childhood and preschool children as a basis for a personal health culture.

It is determined that the effectiveness of the professional competence formation of the future professionals in the process of pedagogical practice depends on qualitative theoretical students training at the disciplines of professional orientation, which contributes to the successful solution of the specific practical problems; the selection of the basic pre-school educational institutions for practical training and psychological and pedagogical support and methodological enforcement of practice.

Key words: pedagogical practice, professional competence, preschool education teacher, competence approach, vocational training, general and professional competences, readiness for pedagogical activity.

UDC 37.013

DOI https://doi.org/10.31392/NPU-nc.series5.2019.71.08

Bulharu N. B.

\title{
BASIC ASPECTS OF THE FORMING PROFESSIONAL COMPETENCIES OF STUDENTS IN A TECHNICAL HIGHER EDUCATION INSTITUTION
}

The article is devoted to the research of the formation of professional competencies among students of technical universities. The issues of training a professionally competent specialist are disclosed in the article. The research by scientists on the formation of competency issues regarding various activities is analyzed in detail. After analyzing the scientific psychological and pedagogical literature it was revealed that at the moment the generally methodological guidelines for the formation and use of funds of assessment tools for assessing competencies have not yet been formed. In particular, among scientists there is no single view on the concept meaning of «competence», "competency» and a clear idea of their relationship. The approaches and forms of work that can meet the current student demand and form the necessary competencies, professional and personal qualities of future specialists are considered in the article. It has been established that it becomes mandatory not only to use new scientific knowledge in the educational process, but also to include creative search in educational activities.

The feasibility of using the competence approach in the vocational training of students of technical universities is substantiated. The theoretical aspects of the system for assessing the level of professional competence are analyzed. The approaches to the interpretation of the concepts of "competency" and "competence» to the characteristic levels of their formation and definition criteria in the scientific and pedagogical literature are considered. The article notes that competence is a personal property of a person, the potential ability and willingness of an individual to cope with various tasks that are formed in the activity and integrate the semantic attitude to it.

The main qualities and criteria of technological effectiveness of the educational process at the university are clearly described in the article. It is reasonably indicated that the scientific and methodological support of vocational training doesn't keep pace with the rapid development of information technologies in the field of education, requires the modernization of the training of future specialists. Therefore, further research is required to identify the factors and conditions for the formation of professional competence using network technologies.

Key words: competency, competence, formation of professional competencies, level of development of professional competence, professional competence of technical universities students.

The relevance of research is determined by the fact that Ukraine's entry into the world educational community causes changes in the nature of vocational education and its orientation to «free development of man», creative initiative, responsibility for the work quality, professional independence, ability to grow professionally and the mobility of future professionals. A university graduate should have both professional and general cultural competencies, because modern conditions in the labor market require universities to train specialists with, have psychological stability, readiness for overload, stressful situations, the ability to go out of them, the ability to work in a team, accept independent decisions, have the initiative, ability to innovate, the ability to make choices, to use limited resources efficiently, perform professional responsibilities, the ability to negotiate and so on [8]. 
The training issue of professionally competent specialist was reflected in the studies of such scientists as N. Volkova, I. Dichkivskaya, Yu. Zhilyaev, G. Kovalchuk, L. Novikova, I. Podlasy, A. Sichkaruk and others. In the scientific literature, the concepts of «competency» and «competence» have been widely used since the mid 60th century becoming the basis for the formation of a competency-based approach to education (N. Chomsky, R. White, J. Ravenna, J. Delors, V. Hutmacher, T. Hoffmann). Nowadays, the scientists continue to explore the formation of competency issues in relation to various types of activities (V. Baidenko, I. Zimnyaya, A. Kasprzhak, V. Landscher, A. Markov, N. Sakharova, Yu. Tatur, A. Khutorskoy, etc.

After analyzing the scientific psychological and pedagogical literature, it was revealed that at the moment the generally accepted methodological guidelines for the formation and application of assessment funds for competency assessment have not yet been formed. In particular, among scientists there isn't consensus on the content notion of «competency», «competence» and a clear idea of their relationship. Therefore, further theoretical development of formation of professional competencies levels is necessary.

The main purpose of the articles is a research the process of formation of professional competencies among students of technical universities. To achieve the target goal, the research object was chosen-students' professional training of higher technical educational institutions; the research subject is the formation of professional competence of students of technical universities; the research task: to analyze the theoretical aspects of the system the level of professional competencies formedness.

Understanding competencies as educational outcomes attempts to build a dialogue between the employer (as a customer of the educational result) and the higher educational establishment (as the provider of educational results) more productive. At the same time, educational technologies are considered as a for method of competencies (through the use of active and interactive teaching methods), and assessment tools (by involving in their development employers, experts from the professional environment) as a proof tool for formation of competencies. Assessment of the level of competence formation is a task that can't be solved only using traditional teaching methods, monitoring and assessment tools.

The question arises, what approaches, forms of work can satisfy the modern student demand, to form the necessary competencies, professional and personal quality of future professionals. The introduction of innovative and information technologies in higher education provides for a more active integration of the educational process and scientific research. Innovative methods provide a raising education, its multifaceted sectors to a qualitatively new level. It becomes obligatory not only the use of the new scientific knowledges in the educational process, but also the inclusion of creative search in educational activities. Solving the problems requires the creation of an effective system of support for gifted student youth, a broader development of forms of research activities of students focused on promising scientific technical directions, the formation of an effective youth science.

According to the pedagogical encyclopedia, the concept of «competence» includes such qualities as initiative, cooperation, ability to work in a group, communication skills, ability to learn, assessment skills, think logically, select and use information [17, c. 237]. N. A. Moreva notes that competence determines the quality and level of professional readiness for activities, which is expressed in the nature of work, the ability to find a rational solution of the problem in the face of various difficulties [10, c. 26]. Afanasyev V. Considers that competencies a set of functions of the rights and obligations of a specialist. Bezrukova V. S. notes that competence is the possession of knowledge and skills that allow you to express professionally competent judgments, opinions, evaluations.

According to Zimnyaya I. A. the competence is «a complex of interdependent aspects of activity related to the accumulation of knowledge that determine the professional core of a specialist; defining an additional alternative industry; orientation to the living room and social values; the development of communicative and pragmatic personality traits; improving the selectivity of the motivation period when choosing the type of activity» [10, c. 26]. As we see a rather ambiguous situation was created regarding the content of «competency», which indicates the lack of development of this concept in the modern educational system. The Competency actualization takes place as a result of the accumulation of experience, «finding and testing various models of behavior in this area, choosing from them those that most closely correspond to his style, claims, aesthetic taste and moral orientations».

Thus, competence is a personal property of a person, a potential ability and willingness of an individual to cope with various tasks that are formed in the activity and integrate a value-semantic attitude to it.

The following components are distinguished in the structure of competence: «psychological component» (academic knowledge, ability to know and understand) «Value component» (value orientations of a person and motivation to solve professional problems) «Activity component» (practical and operational application of knowledge to a specific situation).

Competence is a category that is understood primarily by the employer, it characterizes the professional activity of the graduate and is realized after graduation at the workplace [17, c. 58].

The formation of a particular competency can't always be directly related to the development of any one discipline or a group of disciplines. Competencies are parallel and cumulative during all forms of student work the development of individual disciplines and groups of disciplines, practical training, performing research (research work) and independent work.

The competency model of the graduate is an agreement between consumers (employers, students) and the university regarding the goals and expected results of mastering the public school. 
Competencies are divided into: general cultural (GCK), general professional (GPK), professional (PK), professional and applied (PAK). For example, for the field of knowledge metrology, measuring equipment and information-measuring technologies the specialty of instrumentation have such competencies:

General cultural competency $(G C K)$ - it is the ability to successfully act in solving problems that are general to many types of professional activity. The difficulty assessing of general cultural competencies lies in the fact that their degree of formation is the result of mastering a holistic educational program. An example of general cultural competencies is: the ability to self-organization and self-education; the ability to use basic legal knowledge in various fields of activity; ability to work in a team; tolerantly perceive social, cultural, personal differences.

General professional competency (GPK), as an example is the fundamental knowledge about the principles of building modern information-measuring and computing systems, promising directions for their development. This also applies the ability to collect and analyze scientific and technical information on the research topic, take into account current development trends and use the achievements of domestic and foreign science, engineering and technology in professional activities; ability to professionally operate advanced equipment and devices.

Professional competency $(P K)$ - this is the ability to successfully act when completing a task, solving a problem in a specific professional activity [3, c. 11]. An example of professional competencies is: knowledge of the construction, parameters and characteristics, elemental base, principles of design and programming of microprocessor devices of measuring systems knowledge of the principles of construction and basic characteristics of devices for determining orientation and navigation; ability to assess the level of quality indicators and innovative risks of commercialization of design instrument systems.

Professional and applied competencies (PAK), as an example - the ability to develop methodological and regulatory documents, technical documentation for instrumentation facilities, as well as implement systemic measures to implement developed projects and programs, the ability to apply applied methods of theoretical analysis and calculation of devices and systems; the ability to design instrument systems and technological processes using design automation tools and experience in developing competitive products.

The levels of development of competencies for each implemented training profile are determined by the types of professional activity (core, non-core) and the type of competencies. For each type of professional activity, the level of development of competencies is established. Competencies can be formed at different levels: threshold, basic and advanced.

Competencies are prescribed in the professional education program of the specialty; this is a set of standards of the state standard and the requirements of universities to the level of competence formation at the end of the development of the educational program. It includes: specification of requirements taking into account regional and professionally-oriented specificities of universities; clarification or simplification of the formulation of competence; the level structuring of competencies, indicators and descriptors.

Conclusions. Thus, we analyzed the theoretical aspects of the system for assessing the level of formation of professional competencies, the definition of «competency» and characterized the types of competencies that are illustrated by relevant examples, we can conclude that to solve the problem of forming professional competence of future specialists it is possible through targeted pedagogical management of the educational process optimization. We also want to note that the scientific and methodological support of vocational training doesn't keep pace with the rapid development of information technologies in education, requires the modernization of future specialists' professional training., therefore, further investigation will be required to identify the factors and conditions for the formation of professional competence by means of network technologies based on the introduction of distance learning based on the latest information technologies in vocational education.

\section{Bibliography:}

1. Гаврилова Л. А. Дистанційна освіта. Електронні курси : навчально-методичний посібник для викладачів. Київ : Освіта, 2006. $74 \mathrm{c.}$.

2. Горычева С. Н. Возможности применения методологии «Тuning» в проектировании и реализации ОП : доклад на семинаре «Совершенствование компетентностного подхода в НИУ СГУ», Санкт-Петербург - Пушкин. Учебный центр подготовки руководителей, 10-11 июня 2014.

3. Зимняя И. А. Ключевые компетентности как результативно-целевая основа компетентностного подхода в образовании. Авторская версия. Москва : Исследовательский центр проблем качества подготовки специалистов, 2004. 42 с.

4. Канаев В. І. Дистанційне навчання: технологічні аспекти. Київ : Сучасний гуманітарний університет, 2008. 192 с.

5. Каспржак А. Исследования PISA как основания для принятия управленческих решений. Тенденции развития образования: проблемы управления. Москва : Университетская книга, 2005. С. 244-253.

6. Ковтун Е. Н. Способы оценки уровня сформированности компетенций : доклад на семинаре «Совершенствование компетентностного подхода в НИУ СГУ», Санкт-Петербург - Пушкин. Учебный центр подготовки руководителей, 10-11 июня 2014.

7. Колесникова И. А., Горчакова-Сибірська М. П. Педагогічне проектування : навч. посібник для вищ. навч. закладів ; під ред. И.А. Колесниковой. Київ : «Академія», 2005. 288 с.

8. Кудрявцева Е. И. Современные подходы к проблеме формирования и использования моделей компетенций. Управленческое консультирование. Актуальные проблемы государственного и муниципального управления. 2012. № 1. С. $166-177$.

9. Морева Н. А. Педагогика среднего профессионального образования : учебное пособие для студентов высших учебных заведений. Москва : Издательский центр «Академия», 2001. 272 с. 
10. Пидкасистий П. І. Педагогіка : навчальний посібник для студентів педагогічних ВНЗ і педагогічних коледжів ; під ред. П. І. Пидкасистого. Київ, 2008. 640 с.

11. Педагогика: Большая современная энциклопедия / сост. Е. С. Рапацевич. Минск : Современное слово, 2005.720 с.

12. Сахарова Н. С. Категории «компетентность» и «компетенция» в современной образовательной парадигме. Вестник СГУ. 2006. № 3. C. 51-58.

13. Трайнев В. А., Теплишев В. Ю., Трайнев І. У. Нові інформаційні комунікаційні технології в освіті. Київ : «Дашков і До», 2009. $320 \mathrm{c}$

14. Тартур Ю. Г., Медведев В. Е. Подготовка преподавателя высшей школы: компетентностный подход. Высшее образование в Украине. 2007. № 11. С. 46-56.

15. Хуторской А. Образовательные компетенции в дидактике и методике личностно-ориентированного обучения. Известия МСАО. 2003. № 2. С. 167-171.

16. Гац И. Ю. Формирование фонда оценочных средств образовательных результатов студентов факультета русской филологии. Методические рекомендачии. Москва, 2013.

17. Педагогічний енциклопедичний словник / гл. ред Б. М. Бим-Бад. Київ, 2002. 528 с.

\section{References:}

1. Havrylova L. A. (2006). Dystantsiina osvita. Elektronni kursy: [Distance education. Online Courses:] [navchalno-metodychnyi posibnyk dlia vykladachiv] / L.A. Havrylova.-K.: Osvita [in Ukranian]

2. Gorycheva S. N. (2014). Vozmozhnosti primeneniya metodologii «Tuning»v proyektirovanii i realizatsii OP [Possibilities of applying the «Tuning» methodology in the design and implementation of OP] / Doklad na seminare «Sovershenstvovaniye kompetentnostnogo podkhoda v NIU SGU». Sankt-Peterburg - Pushkin. - Uchebnyy tsentr podgotovki rukovoditeley. 10-11 iyunya. [in Russian]

3. Zimnyaya I. A. (2004). Klyuchevyye kompetentnosti kak rezultativno-tselevaya osnova komptentnostnogo podkhoda $\mathrm{v}$ obrazovanii. Avtorskaya versiya. [Key competencies as an effective and targeted basis for a competency-based approach to education. Author's version] - M.: Issledovatelskiy tsentr problem kachestva podgotovki spetsialistov.. [in Russian]

4. Kanaev V. I. (2008). Distancijne navchannya: tekhnologichni aspekti [Distance learning: technological aspects] / V. I. Kanaev. K.: Suchasnij gumanitarnij universitet [in Ukranian]

5. Kasprzhak A. (2005) Issledovaniya PISA kak osnovaniya dlya prinyatiya upravlencheskikh resheniy [PISA studies as the basis for management decisions] [Tekst] / A. Kasprzhak // Tendentsii razvitiya obrazovaniya: problemy upravleniya. M.: Universitetskaya kniga, 244-253 [in Russian]

6. Kovtun E. N. (2014) Sposoby otsenki urovnya sformirovannosti kompetentsiy [Ways to assess the level of competencies] Doklad na seminare «Sovershenstvovaniye kompetentnostnogo podkhoda v NIU SGU». Sankt-Peterburg - Pushkin. - Uchebnyy tsentr podgotovki rukovoditeley [in Russian]

7. Kolesnykova Y. A. (2005) Pedahohichne proektuvannia [Pedagogical design]: navchan. posibnyk dlia vyssh. navchan. zakladiv / Y. A. Kolesnykova, M. P. Horchakova-Sybirska; Pid red. Y. A. Kolesnykovoi. K.: «Akademiia» [in Ukranian]

8. Kudriavtseva E. Y. (2012) Sovremennye podkhody k probleme formyrovanyia y yspolzovanyia modelei kompetentsyi [Modern approaches to the problem of the formation and use of competency models] / E. Kudriavtseva // Upravlencheskoe konsultyrovanye. Aktualnye problemy hosudarstvennoho y munytsypalnoho upravlenyia, 166-177 [in Russian]

9. Kudryavtseva E. I. (2012) Sovremennyye podkhody k probleme formirovaniya i ispolzovaniya modeley kompetentsiy [Modern approaches to the problem of the formation and use of competency models] / E. Kudryavtseva // Upravlencheskoye konsultirovaniye. Aktualnyye problemy gosudarstvennogo i munitsipalnogo upravleniya, 166-177 [in Russian]

10. Moreva N. A. (2001) Pedagogika srednego professionalnogo obrazovaniya [Pedagogy of secondary vocational education]: Uchebnoye posobiye dlya studentov vysshikh uchebnykh zavedeniy / N.A. Moreva. - M.: Izdatelskiy tsentr «Akademiya» [in Ukranian]

11. Pedagogika: Bolshaya sovremennaya entsiklopediya (2005) [Pedagogy: Big modern encyclopedia] / Sost. E.S. Rapatsevich. Mn.: Sovremennoye slovo [in Russian]

12. Sakharova N. S. (2006) Kategorii «kompetentnost» i «kompetentsiya» v sovremennoy obrazovatelnoy paradigme [Categories «competency» and «competence» in the modern educational paradigm]. [Tekst] / N.S. Sakharova // Vestnik SGU, 51-58 [in Russian]

13. Trainev V. A. (2009) Novi informatsiini komunikatsiini tekhnolohii v osviti [New information communication technologies in education] / V. A Trainev, V. Yu.Teplyshev, I.U.Trainev. K.: «Dashkov i Do» [in Ukranian]

14. Tartur Yu. G. Medvedev V. E. (2007) Podgotovka prepodavatelya vysshey shkoly: kompetentnostnyy podkhod [Higher education teacher training: competency-based approach]. [Tekst] / Yu.G. Tartur. V.E. Medvedev // Vyssheye obrazovaniye v Ukraine, 46-56 [in Russian]

15. Khutorskoi A. (2003) Obrazovatelnye kompetentsyy v dydaktyke y metodyke lychnostno-oryentyrovannoho obuchenyia [Educational competencies in didactics and methods of personality-oriented learning]. [Tekst] / A. Khutorskoi // Yzvestyia MSAO, 167-171 [in Russian]

16. Gats I. Yu. (2013) Formirovaniye fonda otsenochnykh sredstv obrazovatelnykh rezultatov studentov fakulteta russkoy filologii [Formation of a fund of educational tools for students of the faculty of Russian philology] / Metodicheskiye rekomendatsii. Moskva [in Russian]

17. Pedahohichnyi entsyklopedychnyi slovnyk (2002) [Pedagogical encyclopedic dictionary] / hl. red B. M. Bym-Bad [in Ukranian]

Булгару Н. Б. Основні аспекти формування професійних компетентностей студентів технічного $3 В О$

Статтю присвячено дослідженню прочесу формування професійних компетенцій у студентів технічних закладів вищої освіти (ЗВО). У статті розкрито питання підготовки професійно компетентного фахівия. Докладно проаналізовано дослідження науковців щцодо формування питань компетениії відносно різних видів діяльності. Після аналізу наукової психолого-педагогічної літератури виявлено, що на даний момент ще не сформовано загальноприйнятих методичних установок з формування $і$ застосування фондів оиіночних засобів для оцінки компетениій. Зокрема, серед науковців немає єдиного погляду на зміст понять «компетентність», «компетенція» та чіткого уявлення про їх 
співвідношення. У статті розглянуті підходи та форми роботи, які можуть задовольнити сучасний попит студентів, сформувати необхідні компетентності, професійно-особистісні якості майбутніх фахівців. 3'ясовано, щзо обов'язковим стає не тільки використання у навчальному прочесі нових наукових знань, але й включення творчого пошуку в освітню діяльність. Обтрунтовано доиільність використання компетентнісного підходу в професійному навчанні студентів технічних 3ВО. Проаналізовано теоретичні аспекти системи оцінки рівня сформованості професійних компетениій. Розглянуто підходи до тлумачень понять «компетентність» $i$ «компетенція», до характеристики рівнів їх сформованості та критерїв визначення в науково-педагогічній літературі. У статті зазначається, що компетенція є особистісною властивістю людини, потенційною здатністю і готовністю індивіда справлятися з різними завданнями, щзо формуються в діяльності й інтегрують иіннісно-смислове ставлення до неї. У статті чітко охарактеризовано основні якості та критерї технологічності освітнього процесу у ЗВО. Зазначено, щзо науково-методичне забезпечення професійного навчання не встигає за швидким розвитком інформаційних технологій у сфері освіти, щзо вимагає модернізації професійної підготовки майбутніх фахівців, тому потребує подальшого дослідження виявлення факторів та умов формування професійної компетентності засобами мережевих технологій.

Ключові слова: компетентність, компетенція, формування професійної компетентності, рівень розвитку професійної компетентності, професійна компетентність студентів технічних $3 В 0$.

УДК 378.371.134:37.025.8

DOI https://doi.org/10.31392/NPU-nc.series5.2019.71.09

Бурчак С. $O$.

\section{КОМПОНЕНТНІ СКЛАДНИКИ КРЕАТИВНОСТІ МАЙБУТНІХ УЧИТЕЛІВ МАТЕМАТИКИ}

Публікація присвячена визначенню компонентних складників креативності бакалаврів - майбутніх учителів математики. У статті схарактеризовано сутність поняття “структура" в психолого-педагогічних дослідженнях вітчизняних $і$ зарубіжни учених, концептуальну основу для визначення структури креативності майбутніх учителів математики в межах власного наукового дослідження.

Також детально розкрито сутність компонентних складників креативності бакалаврів - майбутніх учителів математики та вказано їх показники. Першим компонентним складником визначено мотиваційно-иіннісний, в якому під мотивачією розуміємо характеристики, притаманні майбутньому креативному вчителю математики, які вмотивують і допоможуть реалізувати відповідні знання під час професійної діяльності.

Другим компонентним складником креативності майбутніх учителів математики визначений когнітивний (знаннєвий), який передбачає повноту, глибину, системність, кількість і якість засвоєних майбутніми вчителями математики знань із комплексу дисииплін (педагогіки, психологї̈, математики, методики навчання математики, інформаційно-комунікаційних технологій тощяо), уявлень про зміст, форми самостійної роботи, умінь планувати свої дї̈, робити умовиводи та загальні висновки щодо професійних питань, у тому числі й розвитку креативності учнів, формування обтрунтованої творчої позищї, здатності прогнозування, комунікативних умінь, умінь приймати нестандартні рішення тощзо. Третім компонентним складником креативності постає операційно-технологічний. В його основу покладено набуття вмінь реалізувати творчі розв 'язання фахових завдань. Четвертий компонентний складник структури креативності визначено як рефлексивний, який надає можливість аналізувати використані креативні вміння та навички на практиці, бачити власні помилки й неточності в роботі, що визначає готовність майбутнього вчителя математики до впевненої, повноцінної креативної діяльності в закладах освіти.

Ключові слова: креативність майбутніх учителів, компонентні складники креативності, розвиток креативності педагогів, вища школа, показники, структурний підхід, соціальні і психологічні фактори.

Розвиток вищої освіти України висуває сучасні вимоги до фахової підготовки студентів закладів вищої освіти, в тому числі й педагогічних. У зв'язку з цим виникає потреба у формуванні й розвитку здібностей особистості, які розкривають ії індивідуальні якості, інтелектуальні можливості й творчий потенціал.

Виникає потреба в застосуванні креативних форм, методів навчання, які розвивають здатність до оригінальної думки та креативної дії. Тому одним із найважливіших завдань системи освіти $є$ забезпечення творчого розвитку особистості, про що наголошується в численних освітніх документах нашої держави. Так, на ролі креативності як особливості професійної підготовки наголошується в законі України "Про вищу освіту" та в декларації Всесвітньої конференції з вищої освіти ЮНЕСКО "Вища освіта у ХХІ столітті: бачення та діï” (1998р.) [7, с. 22], що розглядає креативність як інноваційний навчальний підхід.

Сьогодні, у час стрімких змін вищої освіти особливої актуальності набуває питання розвитку педагогічної креативності особистості, що є одним із базових компонентів не лише вітчизняних стратегічних освітніх, указаних вище документів, а й визначено Радою ЄС одним із чотирьох завдань у межах основної стратегії європейського співробітництва в галузі освіти і професійної підготовки до 2020 року [3, с. 33].

У сучасній освіті креативність педагога виступає як один із провідних факторів успішності навчання. Креативність стає тією якістю, що забезпечує особистості можливість адаптуватися до мінливих умов життя і $є$ запорукою успіху людини у професійній діяльності. Креативність $є$ також важливим чинником розвитку особистості, що визначає її готовність змінюватися і відмовлятися від стереотипів [6, с. 11]. 